kind, water-clear and containing few inclusions, separated out at a much later stage.

Dr. L. J. Spencer, with chemical analyses by E. D. Mountain, and microscopical determination of the pseudomorphs by W. Campbell Smith : A davyne-like mineral and its pseudomorphs from St. John's Island, Egypt. Two small crystals found with peridot, garnierite, etc., showed the physical characters of davyne, but consist of a complex silicate (with sulphate and carbonate) of aluminium, calcium, magnesium, and sodium, together with a considerable amount of water. Pseudomorphs after this material are more abundant: they consist of a complex of hydrated silicates of aluminium and magnesium, together with small amounts of corundum and spinel.

\title{
CORRESPONDENCE.
}

\section{THE NOMENCLATURE OF THE SPILITES.}

SIR,-In his interesting paper under the above title, which appears in the current number of the Geologrcal Magazine, Mr. A. K. Wells criticizes as "unfortunate and misleading" the nomenclature adopted by an unnamed writer in describing the alkaline lavas of Derbyshire as "potash-spilites". As the unnamed (and unrepentant) writer in question, I will, with your leave, make a brief reply.

The unfortunate and, as Mr. Wells informs me, accidental omission of a reference to my paper, ${ }^{1}$ deprives his readers of an easy opportunity of appreciating the reasons which led me, though not without hesitation, to place the Derbyshire rocks with the spilites rather than with the mugearites, although, as I clearly showed, they have undoubted affinities with both. By those reasons, which I need not recapitulate here, I am content to stand.

English and American petrologists do not, as a rule, recognize the (sodic) spilites as a distinct suite of equal rank with the alkaline and calcic suites, but rather as a subdivision of the former. Mr. G. W. Tyrrell pointed this out in a forcible letter which appeared in your pages in the same year (1911) as Messrs. Dewey \& Flett's classical paper.

It seems impossible to doubt that both the (sodic) spilites and the Derbyshire lavas in question are alkaline differentiates from a basaltic magma, evolved under similar geophysical conditions. They are, therefore, closely allied genetically, and the use of the prefix " potash", indicating their chief point of difference, appears quite sufficient to obviate all possibility of " misleading".

15th February, 1923.

H. C. SARgent.

1 "On a Spilitic Facies of Lower Carboniferous Lava-Flows in Derbyshire" : Quart. Journ. Geol. Soc., vol. Ixxiii, pp. 11-25. 